\title{
Association of Human Leukocyte Antigen DQ 1 and Dengue Fever in a White Southern Brazilian Population
}

\author{
José Roberto Polizel, Danilo Bueno, Jeane Eliete L Visentainer, Ana Maria Sell, Sueli \\ Donizete Borelli, Luiza Tamie Tsuneto, Marcia Machado 0 Dalalio, Maria Teresa M \\ Coimbra, Ricardo Alberto Moliterno ${ }^{+}$
}

\author{
Departamento de Análises Clínicas, Universidade Estadual de Maringá, Av. Colombo 5790, 87020-900 Maringá, PR, Brasil
}

Dengue is an infectious disease of viral etiology transmitted by the mosquitoes Aedes aegypti, A. albopictus, and A. scutellaris. It can develop either as a benign form or as a severe hemorrhagic form. Previous work showed an association of the hemorrhagic form with human leukocyte antigens (HLA), suggesting a role of genetic factors in disease susceptibility. Nevertheless, data on HLA association with the classical form of the disease is scarce in literature. Sixty-four patients and 667 normal individuals, living in the state of Paraná, Southern Brazil, were used as test and control group, respectively. The patients developed the disease during a virus 1 dengue outbreak either in Maringá city in 1995 (47) or in Paranavaí city in 1999 (17). The diagnostic was confirmed through serology and/ or viral culture. HLA class I and II typing was performed by the classical microlynfocitotoxicity test using monoclonal antisera and fluorobeads. Qui-square statistical analysis confirmed a positive association with HLA-DQ1 (76.6\% vs 57.7\%; $\mathrm{p}=0.005243 ; \mathrm{p} c=0.026215)$. HLA-DR1 also presented an increased frequency in the test group, not statistically significant after $p$ correction though $(32.8 \%$ vs $15.9 \% ; \mathrm{p}=0.005729 ; \mathrm{p} c=0.080206)$. In conclusion, genetic factors may play a role on the susceptibility to the classical dengue, virus 1, in the Brazilian population. Further independent studies should be performed in the Brazilian population to confirm these preliminary data.

Key words: human leukocyte antigens - dengue fever - Brazil

Dengue is an infectious disease of viral etiology transmitted from man to man by the mosquitoes Aedes aegypti, A. albopictus, and A. scutellaris (Pinheiro \& Rosa 1996). Four types of dengue virus, named serotypes 1, 2, 3, and 4 , have been described. These viruses can cause two forms of clinical disease: a classical dengue fever and a hemorrhagic dengue fever (DHF) (Rigau-Pérez et al. 1998). The classical form is a self-limited disease, representing most of the cases of dengue infection. Some few previous studies showed an association of the hemorrhagic form with human leukocyte antigens (HLA), suggesting a role of genetic factors in disease susceptibility (Chiewsilp et al. 1981, Paradoa et al. 1987). Nevertheless, data on HLA association with the classical form of the disease is scarce in literature (La Fleur et al. 2002), and absent in the Brazilian population.

\section{MATERIALS AND METHODS}

Patients and controls - Sixty-four white Brazilian patients, living in the state of Paraná, Southern Brazil, were serologically typed for HLA class I and II antigens. The ethnicity of the patients was defined through inspection of facial morphological features, hair type, and skin color. Paraná's white population is of predominantly European origin $(80.6 \%)$ with a small but significant contribution of

${ }^{+}$Corresponding author. Fax: $+55-44-261-4431$. E-mail: ramoliterno@uem.br

Received 5 March 2004

Accepted 25 August 2004
African (12.5\%) and Amerindian (7\%) genes (Probst et al. 2000). The group consisted of 27 males and 37 females. Mean age at the time of disease was 44.2 \pm 15.38 . Fortyseven of these patients were infected between January and March, 1995, during an outbreak in Maringá city, PR (Secretaria de Saúde de Maringá 1995). The other 17 patients were infected between January and July of 1999 , during an outbreak in Paranavaí city, PR. The diagnostic of the disease was established clinically according to World Health Organization (WHO 1997), and confirmed through serology (IgM Capture ELISA Kit, BioManguinhos, RJ) and/or virus culture at Paraná's Central Laboratory for Infectious Diseases. All cultures presented the serotype 1 of the virus. The control group is represented by 667 healthy individuals ethnically and geographically matched with the patients. All controls were typed for HLA-A and B. Two hundred and one controls were also typed for HLA-DR and DQ. Peripheral blood from patients and controls were collected after informed consent approved by the Institutional Ethics Committee.

HLA typing - HLA typing was performed according to the microlymphocitotoxicity method using monoclonal antiserum (Terasaki \& Mc Clelland 1964). B and T lymphocytes were isolated by Fluorobeads, and the proportion of dead cells was evaluated by cytofluorocromasia (Bodmer \& Bodmer 1977) under an Alphaphot II microscope. We studied HLA class I and II specificities: 17 HLA-A, 38 HLA-B, 14 HLA-DR, and 4 HLA-DQ.

Statistical analysis - The classical chi-square statistical method, with correction of the $p$ value by the number of independent comparisons made at the same locus, was applied to compare the frequency of HLA antigens be- 
tween patients and controls (Svejgaard et al. 1974). The strength of the association was determined by the odds ratio (OR) according to Woolf's formula (Woolf 1995).

\section{RESULTS}

The HLA antigen frequencies of patients and controls are presented in the Tables I, II, and III. Data shown in Table I revealed an increase of the frequency of the antigen HLA-DQ1 in the patient group (76.6\% vs $57.7 \%$; $p=$ $0.005243 ; p c=0.026215)$. The calculated OR was 2.4, indicating that HLA-DQ1 individuals present a higher chance of developing dengue than individuals not expressing this antigen. The antigen HLA-DR1 also presented an increased frequency in the patients, which was not sustained after $p$ correction though $(32.8 \%$ vs $15.9 \% ; p=$ 0.005729 ; $p c=0.080206$ ).

On the other hand, no association was found with any of the 55 HLA class I antigens tested (Tables II, III).

\section{TABLE I}

Human leukocyte antigen (HLA) DR, and DQ frequencies in a sample of white Brazilian patients with classical dengue fever $(n=64)$ and controls $(n=201)$

\begin{tabular}{lcccc}
\hline HLA & Patients $\%$ & Controls $\%$ & $p$ & $p \mathrm{c}$ \\
\hline DR1 & 32.8 & 15.9 & 0.005729 & $0.080206^{a}$ \\
DR15 & 18.8 & 17.9 & $\mathrm{n} . \mathrm{s}$ & $\mathrm{n} . \mathrm{s}$. \\
DR16 & 7.8 & 4.0 & $\mathrm{~ns}$ & $\mathrm{~ns}$ \\
DR17 & 15.6 & 15.9 & $\mathrm{~ns}$ & $\mathrm{~ns}$ \\
DR18 & 3.1 & 2.0 & $\mathrm{~ns}$ & $\mathrm{~ns}$ \\
DR4 & 10.9 & 19.9 & $\mathrm{~ns}$ & $\mathrm{~ns}$ \\
DR11 & 26.6 & 26.4 & $\mathrm{~ns}$ & $\mathrm{~ns}$ \\
DR12 & 1.6 & 2.0 & $\mathrm{~ns}$ & $\mathrm{~ns}$ \\
DR13 & 29.7 & 15.9 & $\mathrm{~ns}$ & $\mathrm{~ns}$ \\
DR14 & 10.9 & 11.9 & $\mathrm{~ns}$ & $\mathrm{~ns}$ \\
DR7 & 20.3 & 19.4 & $\mathrm{~ns}$ & $\mathrm{~ns}$ \\
DR8 & 14.1 & 7.0 & $\mathrm{~ns}$ & $\mathrm{~ns}$ \\
DR9 & 0.0 & 4.0 & $\mathrm{~ns}$ & $\mathrm{~ns}$ \\
DR10 & 3.1 & 2.5 & $\mathrm{~ns}$ & $\mathrm{~ns}$ \\
DQ1 & 76.6 & 57.7 & 0.005243 & $0.020972 b, c$ \\
DQ2 & 35.9 & 29.9 & $\mathrm{~ns}$ & $\mathrm{~ns}$ \\
DQ3 & 50.0 & 56.7 & $\mathrm{~ns}$ & $\mathrm{~ns}$ \\
DQ4 & 12.5 & 6.0 & $\mathrm{~ns}$ & $\mathrm{~ns}$ \\
\hline
\end{tabular}

$a: p \times 14 ; b: p \times 4 ; c: \mathrm{OR}=2.4 ;$ ns: nonsignificant at 0.05 level; $p$ : probability; $p c$ : corrected probability

\section{DISCUSSION}

The well established risk factors for dengue virus infection are related to reinfestation of a region with $A$. aegypti or the introduction of a new virus serotype into the population (Rigau-Peréz et al. 1998). Warm and humid climate, population density, and housing aspects also influence disease outbreaks. Nevertheless, little information is available on the influence of genetic factors for dengue infection susceptibility (Loke et al. 2002).

In this study, we found a higher frequency of the antigen HLA-DQ1 among classical dengue fever patients, as compared with controls, in a white Brazilian population of the South region of the country. The association with the antigen HLA-DR1 did not sustain statistical significance
TABLE II

Human leukocyte antigen (HLA) A frequencies in a sample of white Brazilian patients with classical dengue fever $(n=64)$ and controls $(n=667)$

\begin{tabular}{lcccc}
\hline HLA & Patients $\%$ & Controls $\%$ & $p$ & $p \mathrm{c}$ \\
\hline A1 & 17.2 & 17.9 & $\mathrm{~ns}$ & $\mathrm{~ns}$ \\
A2 & 42.2 & 47.0 & $\mathrm{~ns}$ & $\mathrm{~ns}$ \\
A3 & 20.3 & 19.3 & $\mathrm{~ns}$ & $\mathrm{~ns}$ \\
A23 & 9.4 & 9.4 & $\mathrm{~ns}$ & $\mathrm{~ns}$ \\
A24 & 23.4 & 17.5 & $\mathrm{~ns}$ & $\mathrm{~ns}$ \\
A25 & 7.8 & 3.3 & $\mathrm{~ns}$ & $\mathrm{~ns}$ \\
A26 & 3.1 & 8.5 & $\mathrm{~ns}$ & $\mathrm{~ns}$ \\
A11 & 18.7 & 11.1 & $\mathrm{~ns}$ & $\mathrm{~ns}$ \\
A28 & 10.9 & 11.1 & $\mathrm{~ns}$ & $\mathrm{~ns}$ \\
A29 & 3.1 & 8.4 & $\mathrm{~ns}$ & $\mathrm{~ns}$ \\
A30 & 7.8 & 7.6 & $\mathrm{~ns}$ & $\mathrm{~ns}$ \\
A31 & 1.6 & 8.4 & $\mathrm{~ns}$ & $\mathrm{~ns}$ \\
A32 & 14.1 & 5.6 & $\mathrm{~ns}$ & $\mathrm{~ns}$ \\
A33 & 7.8 & 3.8 & $\mathrm{~ns}$ & $\mathrm{~ns}$ \\
A34 & 0.0 & 0.0 & $\mathrm{~ns}$ & $\mathrm{~ns}$ \\
A36 & 0.0 & 0.8 & $\mathrm{~ns}$ & $\mathrm{~ns}$ \\
A74 & 0.0 & 0.6 & $\mathrm{~ns}$ & $\mathrm{~ns}$ \\
\hline
\end{tabular}

ns: nonsignificant at 0.05 level; $p$ : probability; $p c$ : corrected probability; $p \times 17$

after correction of the $p$ value by the number of antigens tested in this locus. Nevertheless, it is important to stress that the loss of significance might be a consequence solely of the rigor of the statistical analysis, as the $p$ values without correction for HLA-DR1 and DQ1 are very similar to each other (0.005729 vs 0.005243$)$. A second independent study with a larger patient sample may resolve this issue.

The only other recent study on the association of HLA class II and classical dengue fever (serotypes 2 and 3) found a negative association with allele DR11 and no positive associations, in a Mexican population (La Fleur et al. 2002). The lack of a negative association with HLADR11 in our study could be explained by differences in ethnicity of the populations or by the different dengue virus serotypes presented into the two patient's populations. However, La Fleur's data shows a consistent, but not significant, higher frequency of the HLA-DQ1 associated antigens DR1, DR2, and DR13 in the patient's group (2 times, 2.5 times, and 2.5 times, respectively). Unfortunately, the authors did not test for the HLA-DQ locus. In our study HLA-DR13, and the DR2 subtype DR16, but not DR15, also presented a 2 times higher frequency in the patient's group (Table I).

Moreover, the authors reported a negative association of DHF with HLA-DR4. In our study, though not statistically significant, HLA-DR4 presented a trend to negative association, characterized by a 2 times higher frequency in the control group than in the patients group (19.9\% vs $10.9 \%$, Table I). Negative associations are more difficult to characterize in HLA and disease association studies due to the small frequencies of most of the HLA antigens in the control group. Characterization of further smaller frequencies in the patients' sample requires very large sample size. 
TABLE III

Human leukocyte antigen (HLA) B frequencies in a sample of white Brazilian patients with classical dengue fever $(n=64)$ and controls $(n=667)$

\begin{tabular}{|c|c|c|c|c|}
\hline$\overline{\mathrm{HLA}}$ & Patients \% & Controls \% & $p$ & $p c$ \\
\hline B51 & 15.6 & 19.2 & ns & $\mathrm{ns}$ \\
\hline B52 & 4.7 & 3.6 & $\mathrm{~ns}$ & $\mathrm{~ns}$ \\
\hline B7 & 15.7 & 10.8 & $\mathrm{~ns}$ & $\mathrm{~ns}$ \\
\hline B8 & 9.4 & 10.3 & $\mathrm{~ns}$ & ns \\
\hline B44 & 18.8 & 18.9 & $\mathrm{~ns}$ & ns \\
\hline B45 & 3.1 & 3.4 & $\mathrm{~ns}$ & $\mathrm{~ns}$ \\
\hline B13 & 1.6 & 2.2 & $\mathrm{~ns}$ & $\mathrm{~ns}$ \\
\hline B64 & 4.7 & 3.3 & $\mathrm{~ns}$ & $\mathrm{~ns}$ \\
\hline B65 & 10.9 & 5.8 & $\mathrm{~ns}$ & $\mathrm{~ns}$ \\
\hline B62 & 9.4 & 6.0 & ns & ns \\
\hline B63 & 1.6 & 1.8 & $\mathrm{~ns}$ & $\mathrm{~ns}$ \\
\hline B73 & 0.0 & 0.4 & ns & $\mathrm{ns}$ \\
\hline B75 & 0.0 & 0.3 & ns & ns \\
\hline B76 & 0.0 & 0.1 & ns & $\mathrm{ns}$ \\
\hline B38 & 7.8 & 5.7 & $\mathrm{~ns}$ & $\mathrm{~ns}$ \\
\hline B39 & 10.9 & 4.9 & ns & ns \\
\hline B57 & 1.6 & 7.2 & $\mathrm{~ns}$ & $\mathrm{~ns}$ \\
\hline B58 & 3.1 & 3.0 & ns & ns \\
\hline B18 & 14.1 & 10.5 & ns & $\mathrm{ns}$ \\
\hline B49 & 3.1 & 6.0 & $\mathrm{~ns}$ & $\mathrm{~ns}$ \\
\hline B50 & 3.1 & 4.3 & $\mathrm{~ns}$ & ns \\
\hline B54 & 0.0 & 0.1 & ns & $\mathrm{ns}$ \\
\hline B55 & 1.6 & 2.2 & ns & $\mathrm{ns}$ \\
\hline B56 & 1.6 & 1.0 & $\mathrm{~ns}$ & $\mathrm{~ns}$ \\
\hline B27 & 9.4 & 6.1 & $\mathrm{~ns}$ & $\mathrm{~ns}$ \\
\hline B35 & 25.0 & 25.9 & ns & $\mathrm{ns}$ \\
\hline B37 & 1.6 & 3.1 & ns & ns \\
\hline B60 & 3.1 & 7.5 & $\mathrm{~ns}$ & $\mathrm{~ns}$ \\
\hline B61 & 0.0 & 1.5 & ns & $\mathrm{ns}$ \\
\hline B41 & 1.6 & 3.6 & ns & ns \\
\hline B42 & 0.0 & 1.2 & ns & ns \\
\hline B46 & 0.0 & 0.3 & ns & $\mathrm{ns}$ \\
\hline B47 & 0.0 & 0.3 & ns & $\mathrm{ns}$ \\
\hline B48 & 0.0 & 0.9 & ns & $\mathrm{ns}$ \\
\hline B53 & 1.6 & 3.0 & ns & $\mathrm{ns}$ \\
\hline B71 & 0.0 & 1.2 & ns & $\mathrm{ns}$ \\
\hline B72 & 1.6 & 3.0 & ns & ns \\
\hline B78 & 1.6 & 0.0 & ns & $\mathrm{ns}$ \\
\hline
\end{tabular}

ns: non-significant; $p$ : probability; $p c$ : corrected probability; $p \mathrm{x}$ 38

Flaviviruses, including dengue virus, increase the expression of HLA class I and II molecules on infected cells, and the level of the immune response generated against virus peptides presented by HLA molecules may be responsible for the immunopathology of dengue virus infection (King \& Kesson 2003). Dengue virus-specific CD4 lymphocytes may contribute to immunopathology by lysing virus-infected monocytes, the primary site of virus replication (Kurane et al. 1990). Although HLA class I restricted CD8+ cytololitic lymphocytes are the major cells responsible for clearing virus infected cells, CD4+ dengue specific, HLA class II restricted T cell clones with cytolitic activity have been raised from individuals infected or vaccinated with dengue virus (Kurane et al. 1989, 1995, Green et al. 1993, 1997, Livingston et al. 1994). In that case, the HLA-DQ1 and/or DR1 associations observed could be explained by its higher efficacy in presenting virus 1 dengue epitopes to CD4 cells. HLA-DQ2 sub-types have been associated with the magnitude of Celiac Disease due to its higher efficacy in presenting gluten peptides (Vader et al. 2003).

Alternatively, dengue symptoms may be a consequence of the inability of the immune system to control extended virus replication. In that case, HLA DQ1 could work as a suppressor of the immune response to dengue virus, as suggested by Nishimuras' work (1991) on the role of HLA-DQ in immunity. HLA-DQ1 could also be just a marker for variants of interleukin genes (i, e., tumor necrosis factor alpha) linked to the MHC, as discussed by Makela et al. (2002) with hantavirus infection; or some other HLA linked gene that has the potential to influence the disease outcome.

We found no association of classical dengue fever with HLA class I antigens. HLA class I association had been reported only for DHF or secondary dengue fever infection. Loke et al. (2001) showed positive and negative associations with HLA-A24 and HLA-A33, respectively, in a sample of Vietnamese DHF patients infected with type 2 dengue virus. Positive and negative associations of HLA-A2 and HLA-B13 with DHF have been reported in Thai children infected with various dengue virus serotypes (Chiewsilp et al. 1981). An extended study performed in this population reported associations of class I HLA antigens with $\operatorname{DHF}(\mathrm{A} 2, \mathrm{~B} 51)$ and with secondary dengue fever infections (A0203, B52), but no association with immunologically naive patients with primary infections (Stephens et al. 2002). Our patient sample comprises only virus 1 primary dengue infection. Whether primary dengue infections are not associated with HLA class I antigens is a matter of debate, which can only be settle through further studies in different populations.

In conclusion, data presented in this work suggest the hypothesis of genetic predisposition for Classical Dengue Fever in a white Southern Brazilian population. Further independent studies should be performed in the Brazilian population to confirm this preliminary data.

\section{REFERENCES}

Bodmer WF, Bodmer JG 1977. Cytofluorocromasia. In JG Ray, DB Hare, DE Kayhoe (eds), NIAD Manual of Tissue Typing Techniques, National Institute of Health, Bethesda, p. 31-34.

Chiewsilp P, Scott RM, Bhamarapravati N 1981. Histocompatibility antigens and dengue hemorrhagic fever. Am J Trop Med Hyg 30: 1100-1105.

Green S, Kurane I, Pincus S, Paoletti, E, Ennis FA 1997. Recognition of dengue virus NS1-NS2a proteins by human CD4+ cytotoxic T lymphocyte clones. Virology 234: 383-386.

Green S, Kurane I, Tacket CO, Eckles KH, Vaughn DW, Hoke CH, Ennis FA 1993. Dengue virus-specific human CD4+Tlymphocyte responses in a recipient of an experimental live-attenuated dengue virus type I vaccine: bulk culture proliferation, clonal analysis, and precursor frequency determination. J Virol 67: 5962-5967.

King NJC, Kesson AM 2003. Interaction of falvivirus with cells of the vertebrate host and decoy of the immune response. Immunol Cell Biol 81: 207-216.

Kurane I, Innis BL, Nimmannitya S, Nisalak A, Rothman AL, Livingston, PG, Janus J, Ennis FA 1990. Human immune 
response to dengue viruses. Southeast Asian J Trop Med Public Health 21: 658-662.

Kurane I, Meager A, Ennis FA 1989. Dengue virus-specific human $\mathrm{T}$ cell clones. Serotype crossreactive proliferation, interferon gamma production, and cytotoxic activity. $J$ Exp Med 170: 763-775.

Kurane I, Okamoto Y, Dai LC, Zeng LL, Brinton MA, Ennis FA 1995. Flavivirus-cross-reactive, HLA-DR15-restricted epitope on NS3 recognized by human CD4+CD8- cytotoxic T lymphocyte clones. J Gen Virol 76: 2243-2249.

La Fleur C, Granados J, Vargas-Alarcon G, Ruíz-Morales J, Villarreal-Garza C, Higuera L, Hernandez-Pacheco G, Cutino-Moguel T, Rangel H, Figueroa R, Acosta M, Lazcano E, Ramos C 2002. HLA-DR antigen frequencies in Mexican patients with dengue virus infection: HLA-DR4 as a possible genetic resistance factor for dengue haemorrhagic fever. Human Immunol 63: 1039-1044.

Livingston PG, Kurane I, Lai CJ, Bray M, Ennis FA 1994. Recognition of envelope protein by dengue virus serotypespecific human CD4+CD8- cytotoxic T-cell clones. $J$ Virol 68: 3283-3288.

Loke H, Bethel D, Phuong CT, Day N, White N, Farrar J, Hill A 2002. Susceptibility to dengue hemorrhagic fever in Vietnam: evidence of an association with variation in the vitamin D receptor and FCg receptor IIA genes. Am J Trop Med Hyg 67: 102-106.

Loke H, Bethel DB, Phuong CXT, Dung M, Schneider J, White NJ, Day NP, Farrar J, Hill AVS 2001. Strong HLA class Irestricted $\mathrm{T}$ cell responses in dengue hemorrhagic fever: a double-edged sword? J Infect Dis 184: 1369-1373.

Makela S, Mustonen J, Ala-Houhala H, Hurme M, Partanen J, Vapalahti O, Vaheri A, Pasternack A 2002. Human leukocyte antigen-B8-DR3 is a more important risk factor for severe Puumala Hantavirus infection than the tumor necrosis factor alpha (-308) G/A polymorphism. J Infect Dis 186: 843-846.

Nishimura Y, Kamikawaji N, Fujisawa K, Yoshizumi H, Yasunami M, Kimura A, Sasazuki T 1991. Genetic control of immune response and disease susceptibility by HLA-
DQ gene. Res Immunol 142: 559-566.

Paradoa P, Trujillo Y, Basanta P 1987. Association of dengue hemorrhagic fever with HLA system. Haematologia 20: 8387.

Pinheiro FP, Rosa JT 1996. Dengue. In R Veronesi, R Focaccia (eds), Tratado de Infectologia, Atheneu, São Paulo, p. 201214.

Probst CM, Bompeixe EP, Pereira NF, Dalalio MMO, Visentainer JEL Tsuneto LT, Petzl-Erler ML 2000. HLA polymorphism and evaluation of European, African, and Amerindian contribution to the white and mulatto propulations from Paraná, Brazil. Human Biol 72: 597-617.

Rigau-Pérez JG, Clark GG, Gubler DJ, Reiter P, Sanders EJ, Vorndan AV 1998. Dengue and dengue haemorrhagic fever. Lancet 352: 971-977.

Secretaria de Saúde de Maringá 1995. Boletim Epidemiológico de Maringá, Dengue, Maringá, p. 3.

Stephens HAF, Klaythong R, Sirikong M, Vaughn DW, Green S, Kalayanarooj S, Endy TP, Libraty DH, Nisalak A, Innis BL, Rothman AL, Ennis FA, Chandanayingong D 2002. HLA-A and B allele associations with secondary dengue virus infections correlate with disease severity and the infecting viral serotype in ethnic Thais. Tissue Antigens 60: 309-318.

Svejgaard A, Jersild C, Nielsen S, Bodmer WF 1974. HLA and disease statistical genetic consideration. Tissue Antigens 4: 95-105.

Terasaki PI, McClelland JD 1964. Microdroplet assay of human serum cytotoxins. Nature 204: 998-1000.

Vader W, Stepniak D, Kooy Y, Mearin L, Thompson A, van Rood JJ, Spaenij L, Koning F 2003. The HLA-DQ2 gene dose effect in celiac disease is directly related to magnitude and breath of gluten-specific T cell responses. PNAS 100: 12390-12395.

Woolf B 1995. On estimating the relation between blood group and disease. Ann Hum Genet 19: 251-253.

WHO-World Health Organization 1997. Dengue Hemorrhagic Fever. Diagnosis, Treatment, Prevention and Control, 2nd ed., Geneva, 84 pp. 